Simplified Mandelic Acid Treatment of Urinary Infections

THE use of mandelic acid, a new urinary antiseptic, was the subject of a note in a former issue of NATURE $(136,482 ; 1935)$. In order that the antiseptic action may be exerted, it is necessary for the urine to be acid $(p H$ below $\mathbf{5 \cdot 5}$ ), and this was at first effected by the simultaneous administration of ammonium chloride in an amount of 4-8 gm. daily. Treatment with this agent has now been simplified in various ways, which also tend to reduce the disadvantages of the original method, such as the risk of nausea and vomiting, excessive acidity, and albuminuria with casts. Boots Pure Drug Co., Ltd., Station Road, Nottingham, compound the mandelic acid with acid sodium phosphate as the acidifying agent, with sodium bicarbonate in sufficient quantity to neutralise the acid, and suitably sweetened with saccharin. This preparation is put up under the name of 'Neoket', compound mandelic acid granules, the dose of which is two teaspoonfuls in a little water four times a day. The British Drug Houses, Ltd., Graham Street, London, N.1, make use of ammonium mandelate, which is put in the form of an elixir under the name of 'Mandelix', of which 2 fluid drachms constitutes the normal adult dose. This usually suffices to maintain the requisite acidity; exceptionally, it may be necessary to administer ammonium chloride in addition, for which purpose capsules containing gramdoses are supplied. A 'Mandelix Outfit' contains these agents, together with a testing outfit to ensure the proper urinary acidity. Descriptive booklets may be obtained on application from the two firms named.

\section{Mining in South Australia}

Ww have received from the Department of Mines, South Australia, the "Mining Review", No. 62, for the half year ending June 30, 1935. After some preliminary notes on recent mining legislation, including where and how to get more details for those who require them, there follows a series of reports on Government drilling and Government gold and silver recovery, reports of the Commonwealth Council of Scientific and Industrial Research, reports by the Government assistant geologist and various inspectors of mines, etc. The total value of the mineral production of the State of South Australia from 1841 until 1934 is given as $53 \frac{1}{4}$ million sterling, of which copper ranks for something more than 33 millions, ironstone for $12,200,000$ and gold only for $1 \frac{3}{4}$ millions, the production of the other minerals being unimportant.

\section{Czechoslovak Microchemical Society}

A CzechoslovaK Microchemical Society was founded on April 25 in Prague at a gathering of about two hundred chemists, from both Czech and German scientific and industrial circles. Prof. J. Heyrovský, professor of physical chemistry at the Charles University, known for his microchemical polarographic studies, has been elected president. The Society's activities were inaugurated by a lecture by Dr. C. J. van Nieuwenburg, professor of analytical chemistry in the Delft Technical High School, on
"Why and Where Microchemistry?" Austrian microchemists were represented by Prof. Fritz Feigl, professor of chemistry in the University of Vienna. The Society intends to co-operate with microchemical societies and clubs of England, America, Holland and Austria with the view of establishing an International Microchemical Society. The official title of the Society is "Societas microchemica C.S.R." and its address Prague II, Albertov 2030.

\section{Eugenics Research}

LAST year, a Darwin Research Studentship, tenable for two years, was established by the Eugenics Society in honour of Major Leonard Darwin, the award being made to Dr. R. B. Cattell, director of the School Psychological Clinic of Leicester. Dr. Cattell has been investigating the application of intelligence tests to (a) a typical urban, $(b)$ a typical rural population of school children, to determine the average size of family at each level of intelligence. $\mathrm{He}$ is also applying intelligence tests to adults and children in the same families, to determine the correlation rates between parents and offspring. A second Darwin Research Studentship has now been established by the Eugenics Society on the same terms, for the investigation of racial crossing. The holder of this Studentship, which is of the value of $£ 250$ a year, will begin work in October. The particular aspects of racial erossing to be investigated will be determined after applications have been received.

\section{The 200-in. Telescope Disk}

THE successful casting of the 200-in. telescope disk at the Corning Glass Works, America, has aroused world-wide interest during the past eighteen months. An opportunity is being given to English scientific workers to learn some of the details of this achievement since Dr. J. C. Hostetter, director of development research at the Corning Glass Works, who has been intimately associated with the casting of the disk, is to give an address on the subject on Friday afternoon, July 3, at 4.30 p.m. in the lecture theatre of the Institution of Electrical Engineers, Savoy Place, London. The lecture has been arranged under the auspices of the International Congress on Glass which opens in London on July 2, and Sir William Bragg has kindly consented to take the chair at the lecture. Admission is free and no tickets are required. Further information, however, may be obtained from Prof. W. E. S. Turner, General Organising Secretary, International Congress on Glass, University, Darnall Road, Sheffield, 9.

\section{Royal Geographical Society: Medals and Grants}

His MaJesty THe KING has approved the following awards of the Royal Medals of the Royal Geographical Society : Founder's Medal to Mr. G. W. Murray, director of desert surveys, Egypt, for his long-continued explorations and surveys in the deserts of Sinai and eastern Egypt; for his studies of Badawin tribes, and his unstinted help to desert expeditions; Patron's Medal to Major R. E. Cheesman, for valuable 
service to geography during nine years residence in north-west Ethiopia, including reconnaissance and surveys of the course of the Blue Nile and exploration of Lake Tana and its islands. The Council of the Society has made the following awards: Victoria Medal to Dr. Stanley Kemp, for his work in surveys of the Southern Ocean; Murchison Grant to Mr. Michael Leahy, for his explorations of Central New Guinea ; Back Grant to Muhammad Ayub Khan, for his surveys on three expeditions under the leadership of Sir Aurel Stein in East Persia, 1931-34; Cuthbert Peek Grant to Mr. T. H. Harrisson, to assist him in his proposed expedition to New Guinea; Gill Menorial to Lieut. A. L. Nelson, for his charts of the South Sandwich Group, South Orkneys, and South Shetlands.

\section{Announcements}

THE Secretary of State for the Home Department, the Minister of Health and the Secretary of State for Scotland have appointed Mr. J. F. E. Prideaux, as assistant director of medical services, Ministry of Pensions, to be a member of the Inter-Departmental Committee appointed in April, 1936, to inquire into the arrangements made in Great Britain for the restoration of the working capacity of persons injured by accidents.

THF fifteenth international medical congress known as Les Journées Médicales de Bruxelles will be held at Brussels under the presidency of Prof. Robert Danis on June 20-24. Further information can be obtained from the Secretariat, 141 rue Belliard, Brussels.

The tenth general meeting of the DFChema (Deutsche Gesellschaft für chemisches Apparatewesen E.V.) will take place in Munich on July 10, on the occasion of the general meeting of the Society of German Chemists.

The Senate of Buenos Ayres has passed a Bill whereby 150,000 Argentine pesos (about £8,400) will be allowed yearly for the upkeep of a national institute of physics in its application to human pathology. Dr. Mariano R. Castex has been ap. pointed director.

As International Congress of Anatomy, organised by the Italian Society of Anatomy, in which the corresponding societies of Great Britain, Italy, France, Germany, North America, Poland, Holland, Portugal and Latin America will take part will be held at Milan on September 3-8. Further information can be obtained from the general secretary, 31 Via Mangiagalli, Milan.

THE twenty-fifth anniversary of the Sociedad Astronómica de España y América will be celebrated in Barcelona in October 1936 in connexion with an International Astronomical Exhibition which is being sponsored by the Spanish authorities. Particulars of the meeting can be obtained from the president of the society, Dr. J. Comas Solà, Paso de la Enseñanza, 6, Barcelona.
THe following appointments have recently been made by the Secretary of State for the Colonies : D. W. Bishopp to be economic geologist, British Guiana; F. G. Walton-Smith to be biological assistant, Sponge Fishery Investigation, Bahamas; L. V. Waumsley to be engineer, Posts and Telegraphs Department, Malaya ; F. W. Winckley to be tobacco specialist, Jamaica ; Dr. G. Bryce (senior agricultural officer) to be assistant director of agriculture, Nigeria ; C. J. Tyndale-Briscoe (superintendent of education, Tanganyika) to be director of native education, Northern Rhodesia; R. H. Tyrwhitt-Drake (district surveyor, Kenya) to be director of surveys and land settlement, Zanzibar.

Applications are invited for the following appointments, on or before the dates mentioned:

A teacher of mathematics and a teacher of technical drawing in the Wandsworth Technical Institute, London, S.W.18-The Secretary (June 22).

A lecturer (Grade IIc.) in organic chemistry and an assistant lecturer (Grade III) in chemistry in the University of Birmingham-The Secretary (June 25).

A lecturer in metallurgy in the Chelsea Polytechnic, Manresa Road, London, S.W.3-The Principal (June 25).

A lecturer in metallurgy in the British Foundry School-The Secretary, British Foundry School, Central Technical College, Suffolk Street, Birmingham (June 26).

A male junior assistant chemist in the Royal Gunpowder Factory, Waltham Abbey-The Principal Clerk, Royal Gunpowder and Small Arms Factories, Enfield Lock, Middlesex (June 27).

A teacher of mechanical engineering in the Smeth. wick Municipal College-The Director of Education, Education Offices, 215 High Street, Smethwick (June 27).

An assistant lecturer (Grade III) in physics in the University of Liverpool-The Lyon Jones Professor of Physics (June 30).

A principal of the National Training College of Domestic Subjects, 72 Buckingham Palace Road, London, S.W.1-The Chairman of the Governing Body (June 30).

An assistant physicist (X-ray and radium work) at the Hammersmith and Lambeth Hospitals-The Medical Officer of Health (Staff Division 2), County Hall, Westminster Bridge, S.E.1 (July 1).

An organiser of School Museum Service in Derby. shire-The Director of Education, County Education Office, St. Mary's Gate, Derby (July 7).

A professor of botany in University College, Nottingham-The Registrar (July 11).

A University lecturer in geography in the Univer. sity of Cambridge-Dr. F. C. Phillips, Department of Mineralogy and Petrology (July 15).

An assistant to the chief engineer of the Port of London Authority, London, E.C.3-The General Manager (July 17).

A professor of geology in the University of Aber. deen-The Secretary (August 31). 